\title{
Minority Shareholders: Useful Idiots, Free Riders or the Achilles Heel of the Corporate Idea?
}

\author{
Themistokles Lazarides \\ University of Thessaly, Larissa, Greece \\ Email: themis@themis.gr
}

How to cite this paper: Lazarides, T. (2020). Minority Shareholders: Useful Idiots, Free Riders or the Achilles Heel of the Corporate Idea? Theoretical Economics Letters, 10, 488-499. https://doi.org/10.4236/tel.2020.103031

Received: February 17, 2020

Accepted: May 19, 2020

Published: May 22, 2020

Copyright (๑) 2020 by author(s) and Scientific Research Publishing Inc. This work is licensed under the Creative Commons Attribution International License (CC BY 4.0).

http://creativecommons.org/licenses/by/4.0/

\section{(c) (i) Open Access}

\begin{abstract}
The shareholder is the basis of the corporate idea and framework. Corporate governance protects the rights of shareholders. But not all shareholders have the same power, control or ability to exert their responsibilities and rights. The plethora of legal, regulatory and statutory frameworks and initiatives that are in place to establish a balance of power and control within and beyond the formal organizational pyramid, do not take into account the power and the complexity of relations, alliances and strategies among shareholders, shareholders and managers or shareholders and other stakeholders. Furthermore, main corporate governance theories more or less ignore minority shareholders. They are considered as free riders, useful idiots or just supplemental capital to achieve the goals of the more organized or more powerful shareholders or managers. Their position and bargaining depend on ownership concentration and legal protection. Ownership domination and control are the borderlines of the corporate governance problems especially in Continental Europe corporate governance system. In Continental Europe corporate governance system, the issues or problems that are reported for the Anglo-Saxon system are different: asymmetry of information vs asymmetry of power and control, moral hazard vs moral control, adverse selection vs family loyalty, differences in motives (alignment of interests vs control entrenchment). The paper will address these differences and will argue that best practices as an easy way to uphold pretenses and the "comply or explain" in these circumstances leads to non-compliance and no explanations. Finally, the paper will try to answer the question: Who wants to be a minority shareholder in a corporation that doesn't respect the rights of the individual shareholder or it is dominated completely? The consequences of the fallout or failure of corporate governance in Continental Europe system countries will be shown using the Folli Follie case in Greece. As a conclusion the paper argues that a new framework
\end{abstract}


of corporate governance is needed for countries where ownership concentration is high and legal protection of minority shareholders is poor.

\section{Keywords}

Minority Shareholders, Corporate Governance, Dominant Shareholders, Scandals, Free Riders

\section{Introduction}

The corporate idea is evolved around the individual shareholder. The idea of equality, interest alignment and fair play amongst shareholders and other main stakeholders (i.e. managers) is a fallacy that is common. Shareholders as a group are not homogenous. The idea that all shareholders are equal derives from the "on share-one vote" rule. In real life however power and control are not distributed equally amongst the group.

Regulation; legal framework; corporate statutes; shareholders' social interconnections-dependencies; capital accumulation; market for corporate control; cost, feasibility and efficacy of control and inner environment power games create a more dynamic system of shareholders relations. Moreover, the mix of the previously mentioned variables is not the same amongst countries. Shareholders are providers of capital; they have the potential of involvement in management of the corporation and they have a set of rights (these rights vary from country to country and from corporation to corporation). The most significant rights are the right to decide on the strategy and tactics of the corporation, the right to vote, the right to obtain information and the right to monitor the activities of the corporation and the quality of the decisions made.

The main right of any shareholder is the voting right. The rule "one share-one vote" creates the illusion of equality. Corporation is not democracies, however. Some shareholders accumulate more power by obtaining more share, and therefore have more power over others (dominant shareholders). The introduction of cumulative voting (Bhagat \& Brickley, 1984) as a good practice to empower minority shareholders has dubious effects (Lin \& Chang, 2017). So, individual shareholders with very little power, although in many cases hold the majority of shares, do not have the ability to control (voice their disagreement or interests) dominant stakeholders (major shareholders, managers) and they become the useful idiots of the corporation. They provide the capital, but they do not have any control-influence over the decisions made by the corporations they invest in. The incentive to participate in the corporate decision making process is minimal and the power game is in favor of the dominant stakeholders (Cvijanovic, Groen-Xu, \& Zachariadis, 2019).

These shareholders have few options. The first one is loyalty (to the dominant stakeholders) or the exit option (Hirschman, 1970). When shareholders disagree 
or they believe that their interest is not served with the current strategy made by the dominant stakeholders the only viable choice is the exit and hence they become free-riders. The free-rider problem concludes that no shareholder will monitor dominant stakeholders (Kiefer, Jones, \& Adams, 2017). The paper tries to explore these relations and to acknowledge potential threats of the corporate idea.

The protection of these rights is imperative to uphold the balance of needs. The first need is for corporations to find enough capital to finance their activities and to achieve their goals and the second need is to ensure that, depending on the theory adopted by each scholar or executive of the corporation, stakeholders (stakeholder theory) in general or shareholders (agency theory) receive the benefits that their invested interests deserve.

These rights are in most countries protected by law, regulations in almost every country there are voluntary codes or initiatives of shareholders rights. Even OECD has issued a paper describing the Principles of Corporate Governance (OECD, 2004). The judicial system plays a crucial role in the system of shareholders' rights protection as well as corporate governance and ethics system's effectiveness, the internal control systems and the auditing system.

Not all corporate players in the power and control corporate game do not exert the same authority and effectiveness. The corporate governance systems that were identified (Wang \& Chen, 2006; Weimer \& Pape, 1999) describe a very different inner environment throughout the corporate systems. In Anglo-Saxon system managers seem to be the dominant group, whereas in the Continental European system the controlling shareholders are dominant group of stakeholders. In all systems minority shareholders do play a role. Whether this role is a significant one or not is dependent on the quality of the corporate governance and management system, the law, auditing and judicial effectiveness and the quality of the competition for corporate control.

In the corporate power and control game the rules change, alliances are made, and power has many forms. Voting rights, information, opportunity of exerting control, the ability and opportunity to monitor the operations of the corporation, are some of the instrument of regulating the power game.

Minority shareholders, although they seem to be the largest group and collectively, they have the potential to be the dominant group, they rarely are. This is an outcome the fragmentation of power and their inability to monitor the other groups. The paper focuses on these problems and poses some questions on whether these problems in the contemporary corporate and market environment can have a significant impact on the corporate idea.

\section{Legal and Corporate Governance Systems}

One of the pillars of minority shareholders' protection of power is the legal system. As La Porta et al. (1998) argue there are significant differences amongst the legal systems worldwide. Common law countries are considered to "have the 
strongest legal protection for minority investors while French law provides the weakest protection. German law countries fall in the middle in terms of protection to shareholders" (Krishnamurti et al., 2005). Civil law countries, on the other hand, have different checks and balances to mitigate the problem. Major shareholders have been delegated to protect the rights of minority shareholders. In all cases ownership concentration is crucial for the way the power game is played but has different weight.

The way the legal system affects the corporate environment is debatable. The majority of scholars suggest that it is the legal system that affects directly or indirectly ownership structure, remuneration, capital finance, corporate valuation (Klapper \& Love, 2004; Berkowitz et al., 2003; Beck et al., 2003; La Porta et al. 1999, 2000; Claessens et al., 2000; Lombardo \& Pagano, 2000) and not the other way around. In this respect, if policy makers want to change ownership structure, they simply have to change the legal and regulation framework and the change will come to a reality at the speed of market effectiveness.

During the years that followed the scandals of Enron, Worldcom, etc. Sarbanes-Oxley Act (SOX) and other facsimiles have been enacted across the globe. Lazarides and Drimpetas (2010) argue that these initiatives (legal isomorphism) do not have the desirable effect because the fundamental elements (market liquidity or free float, ownership concentration, market effectiveness, family ownership, etc.) in some countries (Baums, 1993; Kester, 1997; Cuervo, 2002) are quite different and so there is no panacea when it comes to market and corporate structure problems and scandals.

Corporate governance during the last three decades and especially after the major corporate scandals of 2001-2002 and 2008 has emphasized the fact that "firm-level corporate governance matters more in countries with weak shareholder protection and poor judicial efficiency" (Klapper \& Love, 2004). Corporations with bad corporate governance system need a more effective legal and judicial framework to balance for the internal failures or weaknesses.

Shleifer and Vishny (1997) argue that there are other factors (i.e. orientation, ownership concentration and time horizon of economic relationships) that cumulatively must be used to categorize corporate governance systems. Ownership concentration seems to be a key element in corporate governance systems. Miller et al. (2010) calculated a 21\% Herfindahl Index of the Fortune 1000 firms and Céspedesa et al. (2010) they calculated a 33\% whereas Gonzaleza et al. (2017) found a 50\% - 80\% Herfindahl Index for Latin America firms and Chen and Ho (2000) for Asian firms reported a $14 \%$ concentration of ownership. Ali, Chen and Radhakrishnan (2007) report that family firms, of the S and P 500 firms, own on average the $11 \%$ of their firms, while in Continental Europe the ownership percentage is more than $35 \%$. Franks et al. (2008) report that in UK ownership concentration is $18 \%$, while in Germany the percentage is $43 \%$ and in Italy $68 \%$. As it seems where Anglo-Saxon corporate governance system is prevailing ownership concentration is low and in Continental Europe and Asian corporate 
governance systems is higher and, in many cases, exceeds the threshold of 50\%.

\section{Minority Shareholders' Options}

The difference in ownership concentration creates a very different corporate environment and it is the notifying difference between corporate governance systems. In all cases the dominant group Is not minority shareholders. Although the protection of shareholders and especially minority shareholders is a common factor in all initiatives (legal or voluntary), the problem doesn't have the same weight in all countries. There is an apparent proportion of the need to protect and the need to be protected. So, in Anglo-Saxon corporate governance countries the protection is higher. The real problem is that in all the other corporate governance systems the need to protect minority shareholders is not considered as a major issue.

Major or controlling shareholders themselves or as groups (i.e. family) they have the opportunity, ability and motive to participate (low cost, high risk of non-participation because ownership stake is high, and the capital invested is not dispersed) in controlling and monitoring as well in managing the firm. They are controlling the Annual Shareholders Meeting (ASM) and the Board of Directors $(\mathrm{BoD})$. On the other hand, minority shareholders due to lack of coordination, interest misalignment, high cost of monitoring, etc. they are vulnerable to expropriation from other stakeholders like major shareholders and managers. Expropriation can take the form of profit reallocation, assets misuse, transfer pricing, sell bellow market price departments or parts of the firm to other firms that major shareholders own or acquisition of other firms that major shareholders own at a premium (La Porta et al., 2000). As the same authors argue this kind of expropriation "though often legal, have largely the same effect as theft" (p.4). So, dominant stakeholders may use the letter of the law to gain private benefits.

The choices that minority shareholders have are directly related with their ability to exercise and protect their rights. "Facilitation of rights exercise may be possible under some prerequisites: uninterruptible information flow to and from shareholders, active capital and market for corporate control, effective and transparent internal control system, effective and independent Board of Directors, reliable system of transactions, ethical use of power and authority by the dominant group (manages in the case of the Anglo-Saxon countries and dominant shareholders)" (Lazarides et al., 2009).

Hirschman (1970) argues that a minority shareholder has only three choices: exit, loyalty, voice. Having in mind the restrictions of the corporate environment and corporate practices and methods of operations and decision making the voice choice is infeasible. High ownership concentration, the lack of shareholder activism, the cost of monitoring and voting rights rules (Gillan \& Nguyen, 2018), especially when ownership concentration exceeds $50 \%$, empower major shareholders to completely dominate over minority shareholders.

The loyalty choice is a most common one. As Aguilera and Jackson (2003) argue the Continental Europe systems is characterized by commitment by large 
shareholders to their investment and minority shareholders to the leadership and competence of major shareholders. Shareholders are willing to free ride. This is a reverse equilibrium. Shareholders acting orthodoxically do not practice monitor and control, although they welcome any tradeoff benefits of other shareholders' or stakeholders' activity. Board of directors can play a role of champions of the minority shareholders, but as Tosi et al. (2003) show the fail to this role. Financial intermediators play a significant role in enhancing the influence of dominant stakeholders and induce loyalty. The complexity of the financial system and the lack of an active and effective market for corporate control are the some of the factors that dive minority shareholders to, almost, blindly follow the dominant group.

The last, but most common one in case of apparent problems, choice is the exit choice. The exit option seems to be less costly to voice, but in reality, there are significant costs. If the market is adequately liquid the costs or losses may be minimal and hence feasible and attractive to minority shareholders. But even in this situation the exit option has some issues. In order to be attractive as an option the effective market hypothesis must be valid.

The idea that markets can effectively disseminate information and solve all elemental problems of the corporate environment, although attractive, has many faults. There are some events that uncover the infectiveness of markets. The first event is the enactment of a new law or regulation that has an impact on operations and financial performance. The second one is the exposure of a corporate scandal. The study of both events show that minority shareholders do not react as fast as the effective market theory assumes.

As Figure 1 illustrates market is not as efficient as the advocates of efficient market hypothesis (Rossi \& Gunardi, 2018; Malkiel, 2003) would like us to believe. The Figure shows that it took shareholders four (4) months to take the exit option (Arnold \& de Lange, 2005) from the day off the critical announcement until the day the stock price has fallen to the its lowest level. The same lack of immediate reaction can be seen at the Folli Follie graph or equity prices. By that time shareholders lost more than ninety percent $(90 \%)$ of their previous wealth. All this time auditors, managers, CEOs and Presidents of the Board of Directors were complacent in failure to disclose information or to provide any warning sign for the minority shareholders. Several hypotheses can me made about their motives or behavior: speculation, incompetence, fear of persecution, commitment to the family or to dominant shareholders (as their employers), etc. Whatever their motive, the fact is that the minority shareholders were victims to their asymmetry of information.

\section{Useful Idiots, Free Riders or the Achilles Heel of the Corporate Idea?}

The notion that minority shareholders are the corner stone of corporations is not new. The paper argues that this notion is true, but minority shareholders are 


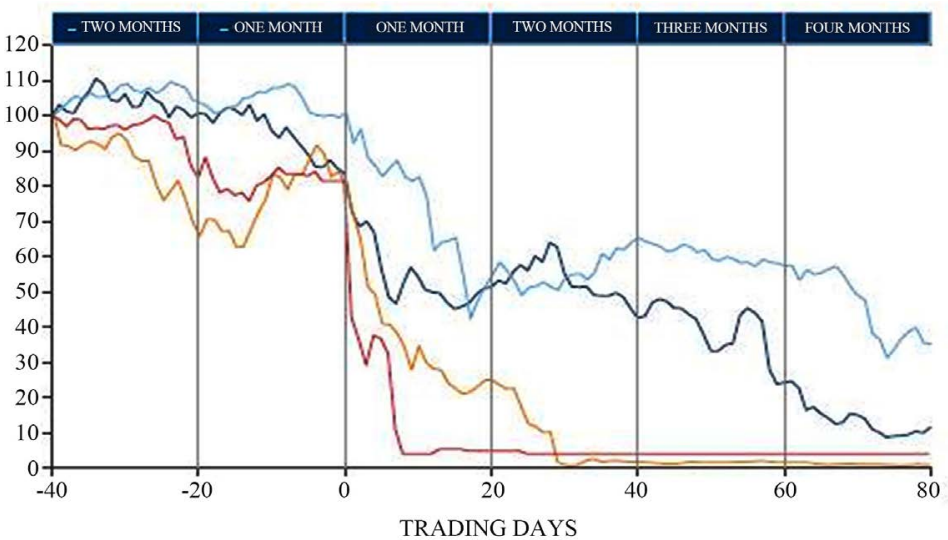

WorldCom (Down 86\%)

Enron Corp (Down 99\%)

Tyco (Down 65\%)

Parmalat (Down 96\%)

Source: ISS (2005)

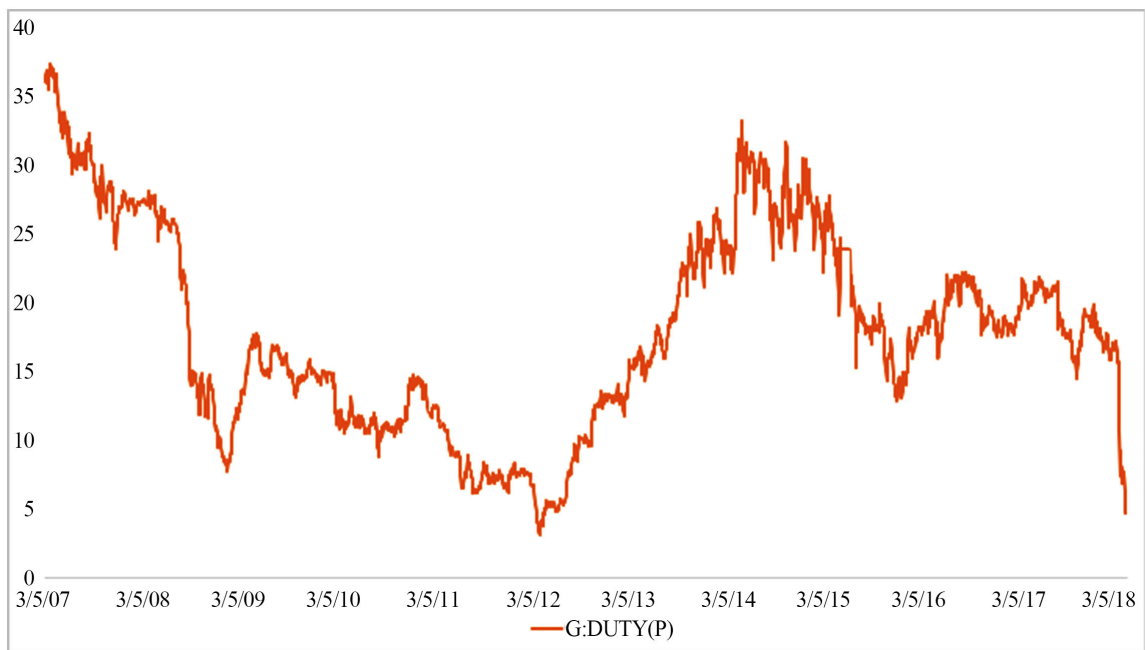

Folli Follie Equity Price

Figure 1. Share Prices two months before and 4 months after corporate failures.

either naïve or instruments-pawns at the hands of dominant stakeholders (managers in the case of Anglo-Saxon countries and major shareholders in the case of Continental Europe countries).

For the minority shareholders to be useful idiots they have to be capital providers, but they do not exert any other right but the right to receive dividends. In this case minority shareholders do not receive, or they do not obtain any useful information about the operations, the quality of decision making or long-term financial performance. The only information they get (regardless their ability or opportunity to process information, to monitor activities and to interpret the news regarding events that took place that affect the corporation) is the information that the dominant stakeholders is willing to give them, in whatever format or quality. Using the Hirschman (1970) classification system of option the useful 
idiot shareholder is the shareholder that uses the loyalty option. Hence, minority shareholders are one of the last groups of stakeholders to react in case of a scandal or an adverse event. When there is a realization of consequences of the scandal the reaction is panic and the immediate collapse of equity prices, even though the cause of the scandal can be traced months or years before the time of the realization. This kind of reaction can be seen at the Folli Follie equity price graph (see Figure 1). According to Financial Times (28/9/2018) the cause of the problem is dated even before 2017 and hence if the effective market hypothesis was valid shareholders could react in 2016 or 2017. But the data show that the reaction to corporate failure happened when there was no doubt that the scandal existed. Even then the reaction wasn't immediate.

If minority shareholders are considered free riders, they are capital providers but there is a constant vigilance regarding the corporate status and performance. Free riders are considered rational and the information they get is enough to give the impression that they can assess the situation at any given time and to react, that is, the illusion of the effective market case is well founded and minority shareholders can exert without costs or losses the exit option. If the free rider hypothesis is valid then minority shareholders should not be loyal to the corporation (long term investors) and abandon (sell) their position at the first sign of problem or divergence of the agreed corporate goals. In this case as well the reaction is not instantaneously to the real event-cause of the failure. Free riders, hypothetically, could react swifter and in advance. Some do (and the majority off the dominant stakeholders do), but the majority of the minority shareholders seem to have a lag time in their reaction. The graph of Enron and WorldCom are representing such a reaction.

Especially in Anglo-Saxon countries the index of free float shows the dependency of corporations to IPOs (see Figure 2) in order to be provided with capital to enhance their activities.

The hypothesis that small capital providers discouraged by scandals and failures (see the number of IPOs during years 2001-2003 and 2008-2009 in Figure 2) lose their faith in the corporate idea and in participating as shareholders in corporations can have momentous consequences. During the years after major corporate collapses-scandals (2001 and 2008) there was a significant drop in the number of IPOs (see years 2001-2003 and 2008-2009 in Figure 2). The cause of this drop in the number of IPOs was that the success of an IPO after a major cluster of corporate scandals and failures is dubious due to the lack of confidence to the corporate idea by minority shareholders. Extrapolating, corporations couldn't finance their growth and be dependent only to capital providers like banks and major shareholders. Corporate risk will be concentrated to only few major shareholders and hence many activities that are now feasible due to risk dissemination to minority shareholders wouldn't be feasible no more. Also, the dependency on banks may increase capital costs and have an impact on financial performance. This could lead to many corporations to failure and the terms of competition could change dramatically. 


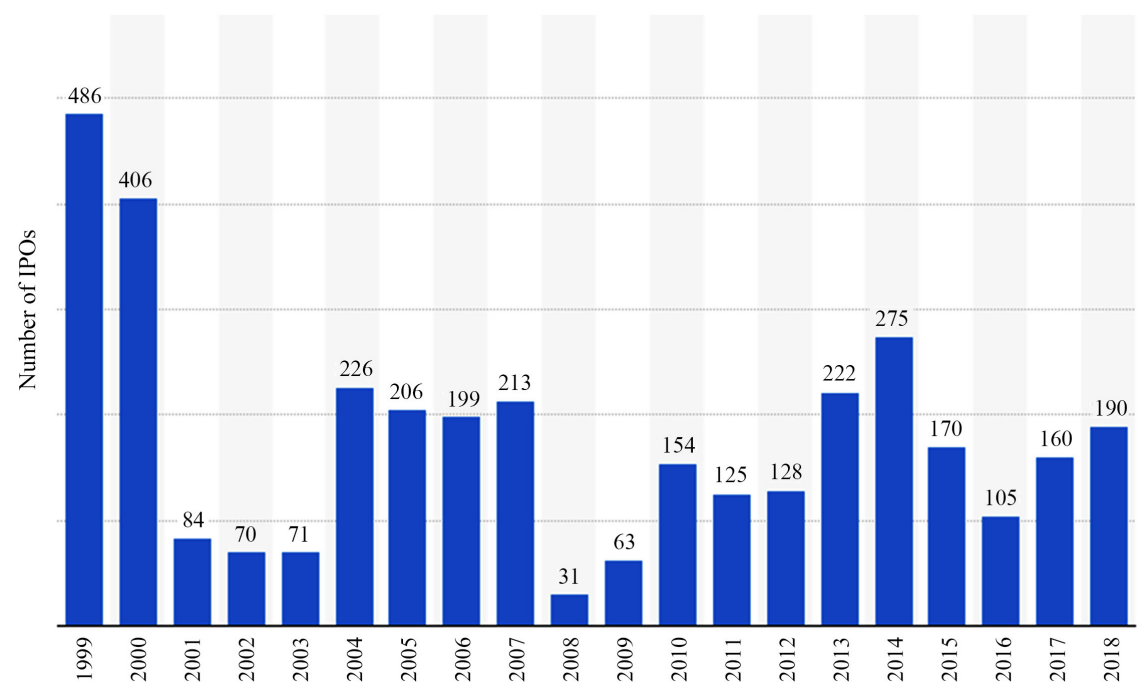

Figure 2. Number of IPOs in the United States from 1999 to 2018

(https://www.statista.com/statistics/270290/number-of-ipos-in-the-us-since-1999/).

\section{Conclusion}

Crossing the ideas of shareholders' choices of Hirschman (1970) and their roles as useful idiots, free riders or the corner stone of the corporate idea, shows that contemporary corporate environment is complex. Minority shareholders are in all corporate governance systems the most vulnerable group of shareholders but there is significant difference in their vulnerability. Legal and judicial protection, and the application of corporate governance principles are crucial to create a stable corporate environment. Failure in these aspects of the environment creates the basis for minority shareholders to be considered as free riders or useful idiots.

As the two examples show regardless the corporate governance system dominant shareholders can and, in many cases, exploit minority shareholders in order to obtain private benefits, to entrench themselves as the dominant group and retain the power and control over corporate assets. Major shareholders and managers as dominant stakeholders do have a fiduciary duty to minority shareholders and to the corporation itself to respect minority shareholders' rights and to reinforce their faith to corporate idea. Failing to do so, will turn minority shareholders to the Achilles heel of modern capitalism.

The paper argues that the foundation of capitalism is the shareholder idea. Good practices (i.e. cumulative voting), codes of corporate governance and ethics, advanced monitoring mechanisms and institutions, new accounting and auditing standards, new regulation schemes, have failed in the past. Corporations have become too big to control and monitor and the minority shareholder is left with only one option, the exit. What is rational in short-term (the exploitation of minority shareholders), is not rational in the long term. The main contribution of the paper is the fact that its purpose is to stimulate awareness and provoke the discussion about the issued raised. 


\section{Limitations and Further Research}

The paper has some limitations. It provides a framework for analysis but it's only just that. It a theoretical framework and it has to be tested empirically. Some evidence has been provided, but further investigation is needed to better establish the framework and hypothesis of the paper. The data needed for an empirical research is limited to a very small number of databases. So, further research is needed. Minority shareholders face different problems, they have different instruments-tools to react and different political, regulatory and legal environment. Taking into account these differences and due to the complexity and diversity of the issue a research for the Anglo-Saxon countries and a separate research for the Continental Europe countries is necessary.

\section{Conflicts of Interest}

The author declares no conflicts of interest regarding the publication of this paper.

\section{References}

Aguilera, R. V., \& Jackson, G. (2003). The Cross-National Diversity of Corporate Governance: Dimensions and Determinants. Academy of Management Review, 28, 447-465. https://doi.org/10.5465/amr.2003.10196772

Ali, A., Chen, T., \& Radhakrishnan, S. (2007). Corporate Disclosure by Family Firms. Journal of Accounting and Economics, 44, 238-286. https://doi.org/10.1016/j.jacceco.2007.01.006

Arnold, B., \& de Lange, P. (2005). Enron: An Examination of Agency Problems. Critical Perspectives on Accounting, 15, 751-765. https://doi.org/10.1016/j.cpa.2003.08.005

Baums, T. (1993). Takeover versus Institutions in Corporate Governance in Germany. In D. D. Prentice, \& P. R. J. Holland (Eds.), Contemporary Issues in Corporate Governance (pp. 151-183). Oxford: Oxford University Press.

Beck, T., Demirguc-Kunt, A., \& Levine, R. (2003). Law, Endowments and Finance. Journal of Financial Economics, 70, 137-181. https://doi.org/10.1016/S0304-405X(03)00144-2

Berkowitz, D., Pistor, K., \& Richard, J. (2003). Economic Development, Legality, and the Transplant Effect. European Economic Review, 47, 165-195. https://doi.org/10.1016/S0014-2921(01)00196-9

Bhagat, S., \& Brickley, J. A. (1984). Cumulative Voting: The Value of Minority Shareholder Voting Rights. The Journal of Law and Economics, 27, 339-365. https://doi.org/10.1086/467069

Céspedesa, J., Gonzálezb, M., \& Molina, C. (2010). Ownership and Capital Structure in Latin America. Journal of Business Research, 63, 248-254. https://doi.org/10.1016/j.jbusres.2009.03.010

Chen, S.-S., \& Ho, K. W. (2000). Corporate Diversification, Ownership Structure, and Firm Value: The Singapore Evidence. International Review of Financial Analysis, 9, 315-326. https://doi.org/10.1016/S1057-5219(00)00032-6

Claessens, S., Djankov, S., \& Lang, L. H. P. (2000). The Separation of Ownership and Control in East Asian Corporation. Journal of Financial Economics, 58, 81-112. 
https://doi.org/10.1016/S0304-405X(00)00067-2

Cuervo, A. (2002). Corporate Governance Mechanisms: A Plea for Less Code of Good Governance and More Market Control. Corporate Governance: An International Review, 10, 84-93. https://doi.org/10.1111/1467-8683.00272

Cvijanovic, D., Groen-Xu, M., \& Zachariadis, K. E. (2019). Free-Riders and Underdogs: Participation in Corporate Voting.

Franks, J. R., Mayer, C., Volpin, P. F., \& Wagner, H. F. (2008). Evolution of Family Capitalism: A Comparative Study of France, Germany, Italy and the UK. In AFA 2009 San Francisco Meetings Paper (pp. 1-44). http://ssrn.com/abstract=1102475

Gillan, S. L., \& Nguyen, N. Q. (2018). When Shareholders and Managers Disagree: Evidence from Shareholder Voting. http://fmaconferences.org/SanDiego/Papers/SOGP01162018.pdf

Gonzaleza, M., Molinab, C., Pabloc, E., \& Rosso, J. (2017). The Effect of Ownership Concentration and Composition on Dividends: Evidence from Latin America. Emerging Markets Review, 30, 1-18. https://doi.org/10.1016/j.ememar.2016.08.018

Hirschman, A. (1970). Exit, Voice, and Loyalty: Responses to Decline in Firms, Organizations, and States. Cambridge, MA: Harvard University Press.

Kester, C. (1997). Governance, Contracting, and Investment Horizons: A Look at Japan and Germany. In D. H. Chew (Ed.), Studies in International Corporate Finance and Governance Systems (pp. 227-242). New York: Oxford University Press.

Kiefer, M., Jones, E. A., \& Adams, A. T. (2017). Shareholders and Managers as Principal-Agent Hierarchies and Cooperative teams. Qualitative Research in Financial Markets, 9, 48-71. https://doi.org/10.1108/QRFM-04-2016-0014

Klapper, L. F., \& Love, I. (2004). Corporate Governance, Investor Protection, and Performance in Emerging Markets. Journal of Corporate Finance, 10, 703-728. https://doi.org/10.1016/S0929-1199(03)00046-4

Krishnamurti, C., Sevic, A., \& Sevic, Z. (2005). Legal Environment, Firm-Level Corporate Governance and Expropriation of Minority Shareholders in Asia. Economic Change and Restructuring, 38, 85-111. https://doi.org/10.1007/s10644-005-4524-4

La Porta, R. F., Lopez-de-Silanes, A., Shleifer, A., \& Vishny, R. W. (1998). Law and Finance. Journal of Political Economy, 106, 1113-1155. https://doi.org/10.1086/250042

La Porta, R., Lopez-de-Silanes, F., Shleifer, A., \& Vishny, R. (1999). Corporate Ownership around the World. Journal of Finance, 54, 471-517. https://doi.org/10.1111/0022-1082.00115

La Porta, R., Lopez-de-Silanes, F., Shleifer, A., \& Vishny, R. (2000). Investor Protection and Corporate Governance. Journal of Financial Economics, 58, 3-27. https://doi.org/10.1016/S0304-405X(00)00065-9

Lazarides, Th., \& Drimpetas, E. (2010). Corporate Governance Regulatory Convergence: A Remedy for the Wrong Problem. International Journal of Law and Management, 52, 182-192. https://doi.org/10.1108/17542431011044634

Lazarides, Th., Drimpetas, E., \& Koufopoulos, D. (2009). Ownership Structure in Greece: Impact of Corporate Governance. The ICFAI University Journal of Corporate Governance, 8, 75-90.

Lin, Y. H., \& Chang, Y. C. (2017). Does Mandating Cumulative Voting Weaken Controlling Shareholders? A Difference-in-Differences Approach. International Review of Law and Economics, 52, 111-123. https://doi.org/10.1016/j.irle.2017.09.003

Lombardo, D., \& Pagano, M. (2000). Legal Determinants of the Return on Equity. Stan- 
ford Law and Economics Olin Working Paper No. 193; and University of Salerno Working Paper No. 24. http://ssrn.com/abstract=209310 https://doi.org/10.2139/ssrn.209310

Malkiel, B. G. (2003). The Efficient Market Hypothesis and Its Critics. Journal of Economic Perspectives, 17, 59-82. https://doi.org/10.1257/089533003321164958

Miller, D., Le-Brettion-Miller, I., \& Lester, R. (2010). Family Ownership and Acquisition Behavior in Publicly-Traded Companies. Strategic Management, 31, 201-223. https://doi.org/10.1002/smj.802

OECD (2004). OECD Principles of Corporate Governance. Paris: OECD.

Rossi, M., \& Gunardi, A. (2018). Efficient Market Hypothesis and Stock Market Anomalies: Empirical Evidence in Four European Countries. Journal of Applied Business Research (JABR), 34, 183-192. https://doi.org/10.19030/jabr.v34i1.10111

Shleifer, A., \& Vishny, R. (1997). A Survey of Corporate Governance. Journal of Finance, 52, 737-783. https://doi.org/10.1111/j.1540-6261.1997.tb04820.x

Tosi, H. I., Shen, W., \& Gentry, R. J. (2003). Why Outsiders on Boards Can't Solve the Corporate Governance Problem. Organizational Dynamics, 32, 180-192. https://doi.org/10.1016/S0090-2616(03)00017-2

Wang, E. T. G., \& Chen, J. H. F. (2006). The Influence of Governance Equilibrium on ERP Project Success. Decision Support Systems, 41, 708-727.

https://doi.org/10.1016/j.dss.2004.10.005

Weimer, J., \& Pape, J. (1999). A Taxonomy of Systems of Corporate Governance. Corporate Governance: An International Review, 7, 152-166.

https://doi.org/10.1111/1467-8683.00143 